\title{
Heat Transfer Analysis in Magnet Housing of Linear Generator using Finite Element Method
}

\author{
Tulus, Ahmad Kamal Ariffin, S. Abdullah and Nurhamidi Muhamad \\ Department of Mechanical and Materials Engineering, \\ Universiti Kebangsaan Malaysia, \\ 43600 UKM Bangi, Selangor, \\ Malaysia \\ Received Date: $28^{\text {th }}$ August 2006 Accepted Date: $7^{\text {th }}$ March 2007
}

\begin{abstract}
This paper presents the heat transfer model of magnet housing in the linear combustion engine incorporating a combustion chamber and a kickback chamber. The heat transfer has been analyzed for the magnet and coils according to heat conducted from combustion and generated by current flowing through coils. By using the finite element method the problem has been analyzed using thermal analysis. The temperature distribution in magnet surrounding is considered. The results show that most of heat comes from the combustion chamber. The heat generated by the coils can rise the magnet temperature. The temperatures in the magnet are between $375 \mathrm{~K}$ and $382 \mathrm{~K}$.
\end{abstract}

Keywords: Linear generator engine, heat transfer, finite element method.

\section{ABSTRAK}

Kertas kerja ini membentangkan model pemindahan haba rumah magnet di dalam enjin pembakaran linear yang menghubungkan kebuk pembakaran dan kebuk tendang balik. Pemindahan haba telah dianalisis bagi magnet dan gegelung mengikut kepada haba yang dialirkan dari pembakaran dan yang dijana oleh arus yang mengalir melalui gegelung. Masalah dianalisis menggunakan kaedah unsur terhingga untuk analisis terma. Taburan suhu di dalam daerah sekitar magnet diperhatikan. Hasil menunjukkan bahawa haba paling besar datang dari kebuk pembakaran. Haba yang dijana oleh gegelung boleh menaikkan suhu magnet. Suhu di dalam magnet adalah di antara $375 \mathrm{~K}$ dan $382 \mathrm{~K}$.

Kata kunci: Enjin penjana linear, pemindahan haba, kaedah unsur terhingga.

\section{INTRODUCTION}

Linear electric generator is an electromechanical energy converter driven by a reciprocating prime mover. Linear electrical generator driven by a free piston combustion engine is developed for practical applications in automotive and remote or standby generation. Usually, the linear generators are designed such that electricity is generated directly from the piston's oscillating motion back and forth through the alternator's coils. Van Blarigan (2001) has designed a linear generator such that the earth permanent magnets 
are fixed to the piston. A number of researchers have designed linear generators such that the earth permanent magnets are connected to the piston by a rod. It has a number of advantages over the conventional rotary generator driven by internal combustion engine. In particular, the linear system gains improvement in efficiency and volume reduction. In this paper, a linear generator engine is considered incorporating combustion and kickback chambers as depicted in Figure 1.

Heat transfer analysis is very important for components around magnet housing of a linear generator engine to evaluate the effect of temperature to the magnet. Wan Mahadi et al. (2004) stated that the intensity of magnetization and the coercive force are elements, which determine the performance of permanent magnets. Most of linear generator designs, such friction, and kickback chamber. Heywood (1988) found that the peak burned gas temperature in the cylinder of an internal combustion engine is of order $2500 \mathrm{~K}$ and the maximum temperature at the piston crown can rise to $550 \mathrm{~K}$. This paper analyzes the heat transfer in the components of the linear generator engine around the magnet housing using the finite element method. The results of this analysis will be depicted as a temperature distribution in the magnets.

\section{GOVERNING EQUATION}

The governing equation of heat generation is considered as the total of heat generated by combustion, coil heat dissipation, and friction, and can be represented as

$$
\sum f(Q)=f\left(Q_{c}+Q_{E}+Q_{f}\right)
$$

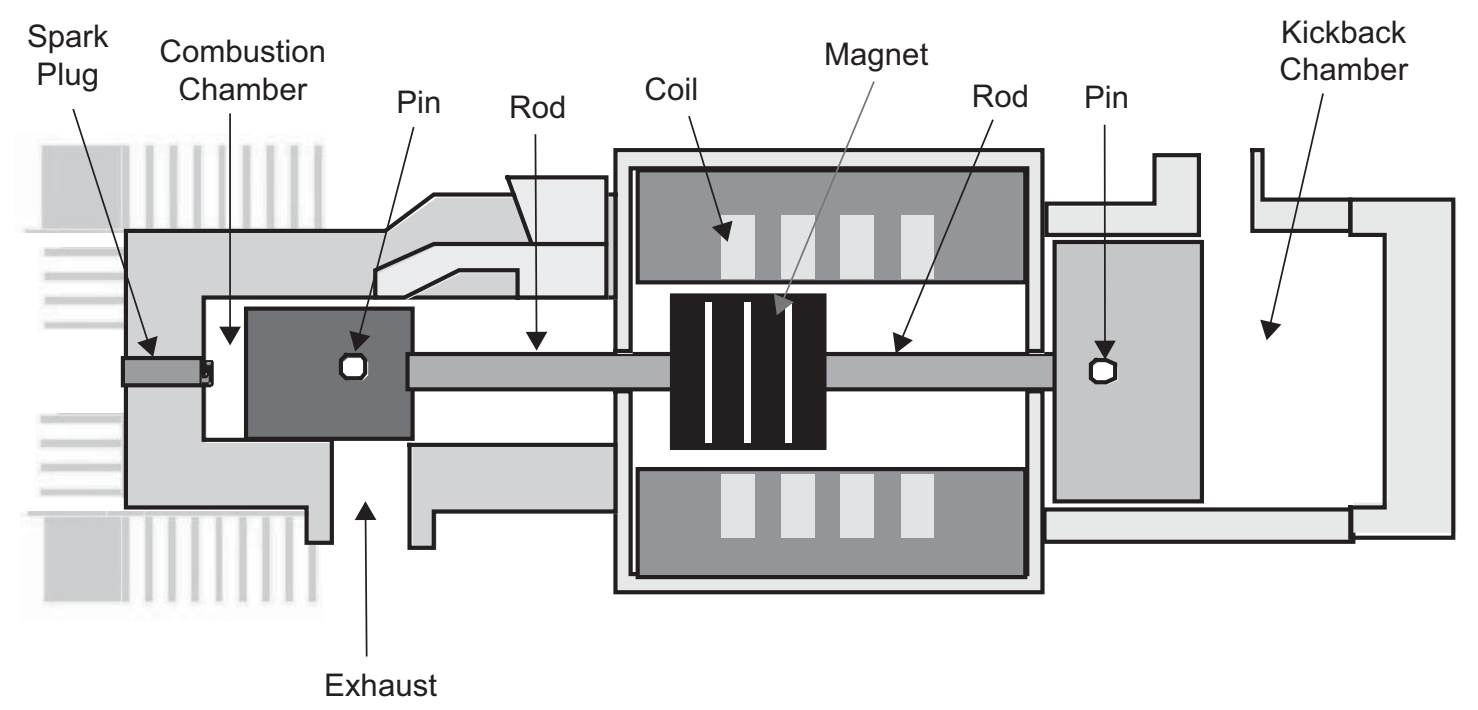

FIGURE 1. Linear generator engine

as that designed by Van Blarigan (2001), use rare earth permanent magnets, Neodymium Iron Boron. According to Stanford Magnets Company (2005), the permanent magnets have the Curie temperature of $350^{\circ} \mathrm{C}$ and the maximum operating temperature of $200^{\circ} \mathrm{C}$. Wan Mahadi et al. (2003) have analyzed the temperature distribution in the permanent magnet, and the results are that the range of temperature distribution in permanent magnet is between $70.2^{\circ} \mathrm{C}$ and $132.9^{\circ} \mathrm{C}$.

In the linear generator engine, heat is primarily generated by combustion and conducted to the magnet through the piston, pin and rod. Another heat is generated by coil's heat dissipation, where $Q_{C}, Q_{E}$ and $Q_{f}$ are heat generated by combustion, electricity and friction, respectively. The heat generated by combustion depends on the dimension of cylinder bore, fuel, air-fuel ratio, and lower heating value. Usually the heat generated by combustion is called as heat addition, $Q_{\text {in }}$. The heat from combustion chamber is transferred to the cylinder head, cylinder block and piston crown. Tulus et al. (2004) has derived the equation to determine the temperature around combustion chamber for two-stroke linear engine as follows.

$$
Q_{i n} \frac{d x_{b}}{d t}-\frac{d Q_{w}}{d t}=P \frac{d v}{d t}+m c_{v} \frac{d T}{d t}
$$


The heat transfer by conduction, per unit area per unit time, $\dot{q}$, in steady situation is given by Fourier's law

$$
\dot{q}=-k \nabla T
$$

Frictional heating is a friction of sliding velocity, bearing pressure and coefficient of friction. The heat generated by friction can be formulated as

$$
Q_{f}=\eta F_{f} v_{f}
$$

In the paper written by Ghosh \& Brewe (1995), the steady state or transient heat transfer in a three dimensional anisotropic solid moving with velocity $v$ is governed by Fourier heat conduction or energy equation, which is written as

$$
\nabla \cdot k \nabla T-\rho c\left[\left(\frac{\partial T}{\partial t}\right)-v \cdot \nabla T\right]+\dot{Q}_{f}=0
$$

The heat from the piston that comes from combustion chamber and ring piston friction is conducted to the magnet through piston pin and rod.

The processes of transfer in a transformer and interaction in a machine involve current (and therefore $l^{2} R$ loss) in conductors and fluxes (producing core loss) in ferromagnetic circuits by Say (1976). As all losses appear as heat, the temperature of each part so affected is raised above that of the ambient medium (normally the surrounding air). The temperature-rise above ambient is related (i) to the rate of heat production, (ii) the rate of cooling and (iii) the thermal capacity. Heat is removed by a combination of conduction and convection, assisted by radiation from outer surfaces.

The heat generated by heat dissipation in the coil is transferred to magnet through convection and radiation. Heat generation in linear generator refers to resistance heating in copper wire where electrical energy is converted to heat. The heat generation can be represented as

$$
Q_{E}=\frac{I^{2} R_{c o i l}}{\pi\left(r_{0}^{2}-r_{i}^{2}\right) L}
$$

In the convective heat transfer problem, the steady-flow forced convection and natural convection is considered. The heat flux $\dot{q}$, transferred to a solid surface at temperature $T_{w}$ from a flowing fluid, stream at temperature $T$ is determined from the relation

$$
\dot{q}=h_{c}\left(T-T_{w}\right)
$$

The heat transferred by radiation can be represented as

$$
\dot{q}=\sigma\left(T_{g}^{4}-T_{w}^{4}\right)
$$

where $T_{g}$ and $T_{w}$ are the gas temperature and surface temperature, respectively.

\section{ANALYSIS USING FINITE ELEMENT METHOD}

Referred to (MacNeal, 1972), the general equation that is solved when finite element methods are applied to heat transfer analysis may be written in the form.

$$
[K]\{u\}+[B]\{\dot{u}\}=\{P\}+\{N\}
$$

The geometry model is in three-dimensional. The dimensions of some components that are important to the analysis are as in the Table 1.

The material properties applied to the solids of model are referred to some references, for example Cengel (2003). The parameters that have to be applied to the parts of model due to thermal analysis are density, specific heat and thermal conductivity. The boundary conditions applied to the model are temperature distribution near spark plug, applied heat at the contact surfaces of the pistons to the cylinder walls and contact surfaces of bushing to the

TABLE 1. Dimension of a number of components that important for calculation

\begin{tabular}{lclc}
\hline \multicolumn{1}{c}{ Components } & Dimension & \multicolumn{1}{c}{ Components } & Dimension \\
\hline Cylinder bore diameter & $76 \mathrm{~mm}$ & Air gap & $1 \mathrm{~mm}$ \\
Magnet thickness & $15 \mathrm{~mm}$ & Coil inner diameter & $60 \mathrm{~mm}$ \\
Wire width & $4.38 \mathrm{~mm}$ & Coil outer diameter & $118 \mathrm{~mm}$ \\
Wire thickness & $1.75 \mathrm{~mm}$ & Wire length per Coil & $58.7 \mathrm{~mm}$ \\
\hline
\end{tabular}


rod, volumetric heat in the coils, radiation from coils to magnets, convection to the ambient and coupled convection between two solids which are not connected to each another.

The model and the meshing are depicted in Figure 2, the mesh for pistons, rod and magnet in Figure 3(a), and the mesh for magnet and housing in Figure 3(b).

The heat conduction matrix for a volume heat conduction element is derived from a thermal potential function. The thermal potential function is

$$
U=-\frac{1}{2} \int_{V} \tilde{q} \cdot \nabla u d V
$$

The components of the heat flux are related to the components of temperature gradient by

$$
q_{i}=-\sum_{j} k_{i j} \frac{\partial u}{\partial x_{j}}
$$

Using equation (11), equation (10) can be expressed in matrix form as

$$
U=-\frac{1}{2} \int_{V}\left[\frac{\partial u}{\partial x_{i}}\right]\left[k_{i j}\right]\left\{\left[\frac{\partial u}{\partial x_{j}}\right]\right\} d V
$$

The temperature, $u$, at an interior point is a linear combination of the temperature, $\left\{u_{e}\right\}$, at the vertices of the element,

$$
u=\left[L_{e}\right]\left\{u_{e}\right\}
$$

The thermal gradient vector is, therefore
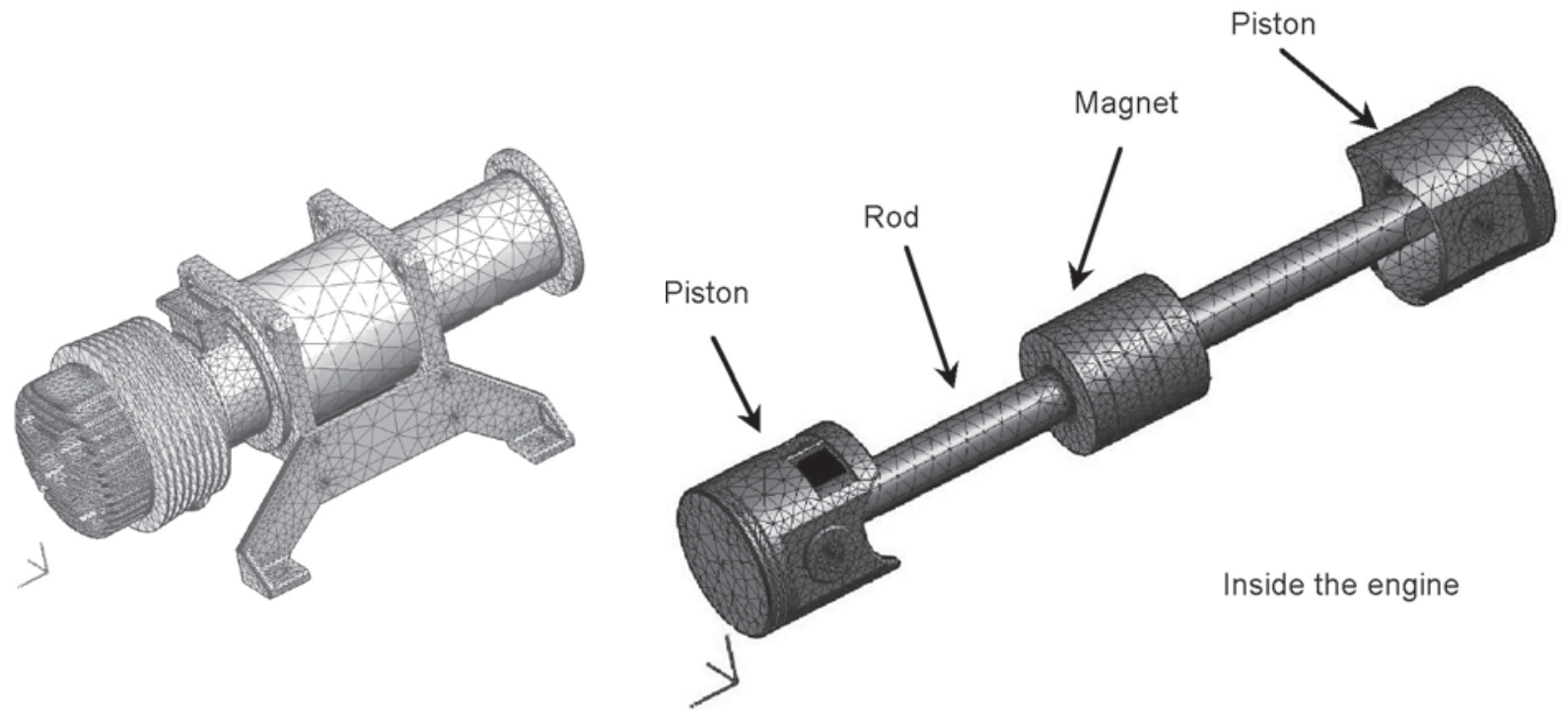

FIGURE 2. Global model and meshing

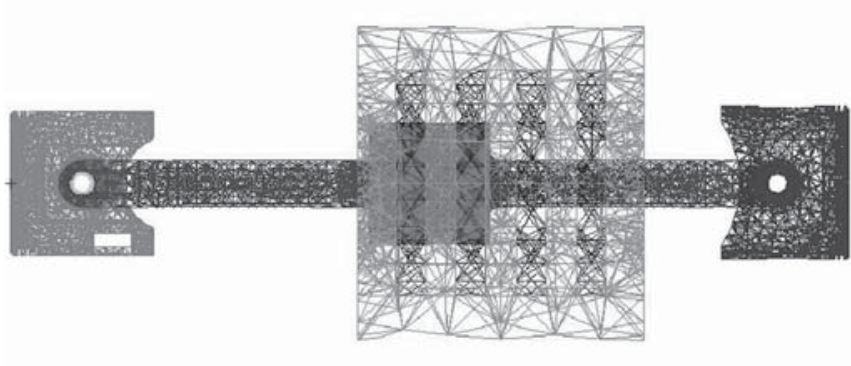

(a)

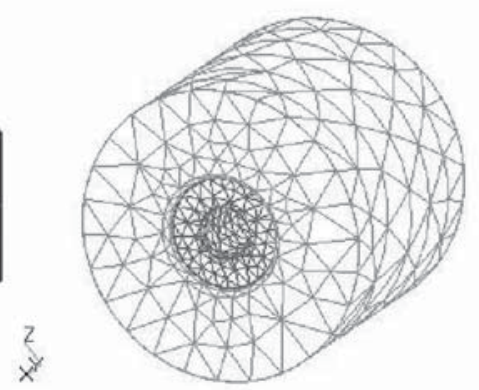

(b)

FIGURE 3. Mesh of pistons, rod and magnet housing 

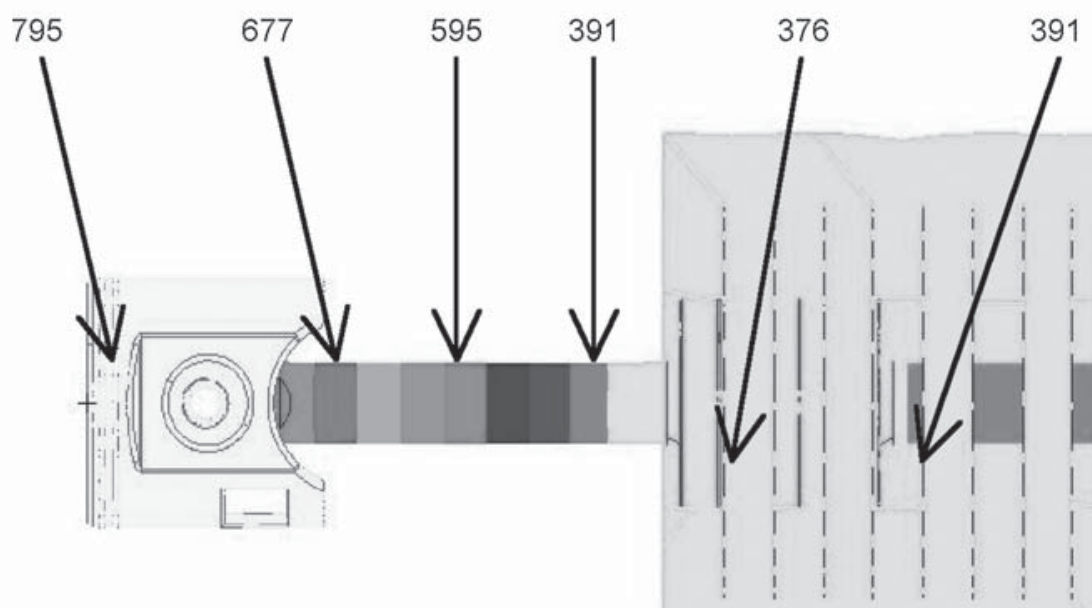

$6.77+002$

$6.36+002$

$5.95+002$

$5.54+002$

$5.14+002$

$4.73+002$

$4.32+002$

$3.91+002$

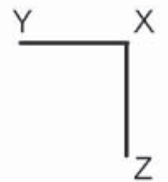

$3.50+002$

default_Fringe:

Max6. $00+002 @ N d 223856$

Min 3.50+002 @Nd 95435

FIGURE 4. Temperature distribution from combustion piston to kickback piston

$$
\left\{\frac{\partial u}{\partial x_{j}}\right\}=\left[L_{e, j}\right]^{T}\left\{u_{e}\right\}
$$

The number of rows and columns of $\left[L_{e, j}\right]$ are the number of vertices of the element and the dimension of the space, respectively. The substitution of equation (14) into equation (12) produces an expression with the form

$$
U=\frac{1}{2}\left[u_{e}\right]\left[K^{e}\right]\left\{u_{e}\right\}
$$

where the element heat conduction matrix is

$$
\left[K^{e}\right]=\int_{V}\left[L_{e, i}\right]\left[k_{i j}\right]\left[L_{e, j}\right]^{T} d V
$$

\section{RESULTS AND DISCUSSION}

According to the dimension in Table 1, by applying the stoichiometric LHV of gasoline $2.96 \mathrm{MJ} / \mathrm{kg}_{\text {air }}$ from Tulus et. al. (2004) the peak temperature near the spark plug is $850 \mathrm{~K}$. For the analysis, the temperature applied to the cylinder head is assumed $800 \mathrm{~K}$ and the ambient temperature is assumed $350 \mathrm{~K}$.

Referring to the Table 1, the wire width of $4.38 \mathrm{~mm}$ and thickness of $1.75 \mathrm{~mm}$, so the wire cross section area is $7.665 \mathrm{~mm}^{2}$. This area is equal to the area of wire of diameter $3.124 \mathrm{~mm}$ that correspond to 122.99 mils. Based on the data AWG table and by using curved fitting method, the resistance of the wire becomes $0.460 \mathrm{hm} / 100 \mathrm{M}$. One coil needs $57.40 \mathrm{M}$ long of wire. So, the 
resistance of wire in one coil $R=0.260 \mathrm{hm}$. By assuming that the current, $l$, is $22.5 \mathrm{~A}$. So the heat dissipation, $Q_{E^{\prime}}$ for one coil $R^{2} R=105.2366 \mathrm{~W}$.

Figure 4 shows the temperature distribution from piston in combustion chamber to magnet housing. The temperature $800 \mathrm{~K}$ at the piston crown is reduced to $393 \mathrm{~K}$ near magnet. On the other hand, Figure 5 shows that the range of temperature of magnets is between $375 \mathrm{~K}$ and $382 \mathrm{~K}$. This range can be accounted as a safety margin for the permanent magnet which has maximum operating temperature of $200^{\circ} \mathrm{C}$ (473K).Comparing the results from (Wan Mahadi et al.2003) and (Wan Mahadi et al.2004), that the temperature difference in the magnet is more than $62 \mathrm{~K}$ and $90 \mathrm{~K}$, respectively, the resulting temperature distribution range of $7 \mathrm{~K}$, that is $(382$ - 375) $\mathrm{K}$ in the magnet is more reasonable.

From Figure 5, some heat from coils are transferred to the magnets, so that the temperature of the magnet near coils of $379 \mathrm{~K}$ to $382 \mathrm{~K}$ are higher then the temperature of other side of $375 \mathrm{~K}$ to $379 \mathrm{~K}$. It means that the heat from coils can influence the temperature of magnet. It can be also seen that most of heat from coils are conducted to magnet housing. From the figure, the temperature of two inner coils is higher than the two outer coils, i.e. $386 \mathrm{~K}$ to $390 \mathrm{~K}$ and $380 \mathrm{~K}$ to $386 \mathrm{~K}$, respectively. The temperature distribution of the housing near the coils is between $364 \mathrm{~K}$ to $384 \mathrm{~K}$.

Figure 6 shows the temperature distribution of the outside part of magnet housing. The heat is conducted here to the outer surface and transferred using convection to the ambient.

\section{CONCLUSIONS}

It can be concluded that the finite element method can be used to analyze the thermal model in the linear generator engine. The most of heat in the engine is generated by combustion. The heat

MSC Patran 23003 r2 01-Mar-05 22:28:24

Fringe: SC1: DEFAULT, A3: Non-linear: $100 \%$ of Load: Temperatures. -(NON-LAYERED)

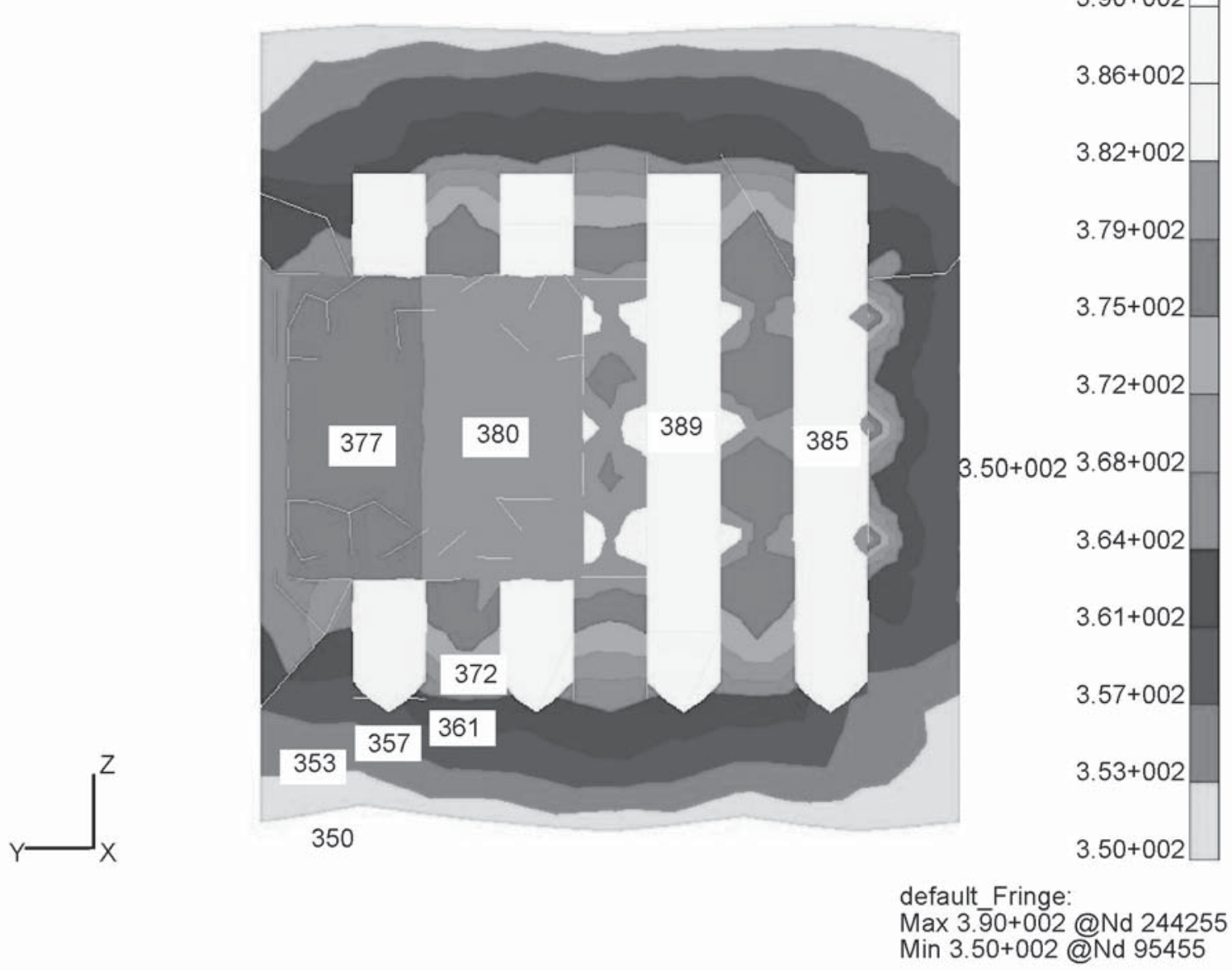

FIGURE 5. Temperature distribution in magnet, coils and magnet housing 
MSC Patran 2003 r2 01-Mar-05 22:25:50

Fringe: SC1:DEFAULT, A3: Non-linear: $100 \%$ of Load: Temperatures. -(NON-LAYERED)

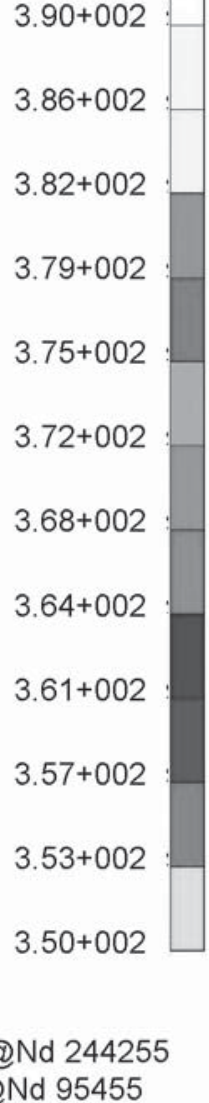

FIGURE 6. Temperature distribution from magnet to outside of magnet housing

generated by combustion that is conducted by piston, pin and rod influenced the temperature raise of the magnet. The heat generated by the coils can raise the magnet temperature. The temperature range in the magnet is between $375 \mathrm{~K}$ and $382 \mathrm{~K}$. It means that the temperature of the magnet does not exceed the maximal operation temperature. Most of the heat in the coils is transferred by conduction to magnet housing and to the ambient by convection.

\section{ACKNOWLEDGEMENTS}

The authors would like to thank the Malaysia Ministry of Science, Technology and Innovation for sponsoring this work under the project IRPA 03-02-02-0056-PR0025/04-03.

\section{NOMENCLATURE}

[B] symmetric matrix of constant heat capacity coefficients

$c_{v} \quad$ constant volume specific heat

$\left[\frac{\partial u}{\partial x_{i}}\right]$ row vector of the partial derivative $\frac{\partial u}{\partial x_{i}}$

$\left\{\frac{\partial u}{\partial x_{j}}\right\} \quad$ vector of the partial derivative $\frac{\partial u}{\partial x_{j}}$

$\eta \quad$ user specific factor

$F_{f} \quad$ friction force 


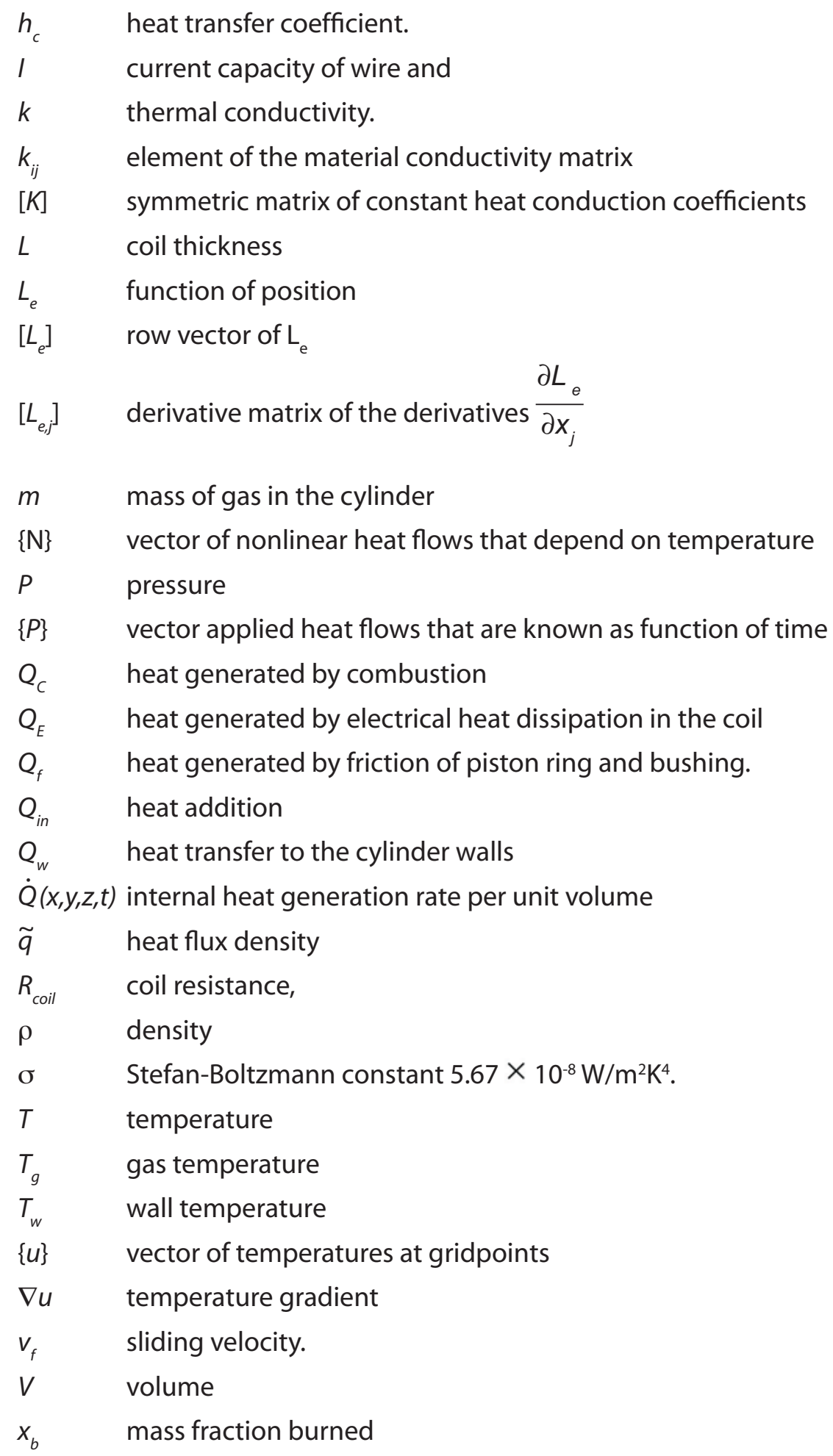

\section{REFERENCES}

Cengel,Y.2003. Heat transfer, McGraw-Hill, Singapore, ePanorama.net http://www.epanorama.net/ documents/wiring/wire_resistance.html.

Ghosh, M. K \& Brewe, D. E. 1995. Temperature distribution and thermal distortion due to frictional heating in a dry shaft-bush tribosystem using the finite element method, Int.J.Mech.Sci. 37(9): 1021-1034.
Heywood, J.B. 1998. Internal combustion engine fundamentals, New York: McGraw-Hill.

MacNeal, R. H. 1972. The Nastran Theoretical Manual, Vol. 2, MSC.Software, USA.

Say, M. G. 1976. Alternating Current Machines, Fourth Edition, The English Language Book Society and Pitman. 
http://www.stanfordmagnets.com/magnet.html (February 22, 2005).

Tulus, Ariffin A. K. , Abdullah S. \& Muhamad N. 2004. Mathematical Modeling of Heat Transfer in Combustion Chamber of Two-Stroke Linear Engine, Proceeding of $12^{\text {th }}$ Mathematical Sciences National Symposium. Bangi, Malaysia, May 2527,2005, pp.324-330.

Van Blarigan, P. 2001. Advanced internal combustion electrical generator, Proceedings of the 2001 DOE Hydrogen Program Review, NREL/CP-57030535 .
Wan Mahadi, W. N. L., Adi, S. R., \& Nor, K. M. 2003. Application of the rare earth permanent magnet in linear generator driven by an internal combustion engine, Proceeding of PECon, Bangi, pp. 256-261.

Wan Mahadi, W. N. L., Adi, S. R., \& Nor, K. M. 2004. Thermal analysis of Neodymium Iron Boron (NdFeB) magnet in the linear generator design, Proceeding of AUPEC'4. http://www.itee.uq.edu. au/ aupec/aupec04/papers/paperID124.pdf[27 May 2006]. 